\title{
Development of Creative-Thinking Instrument in Mathematics Problem Solving Based on Logical Mathematics Intelligence
}

\author{
Luh Putu Widya Adnyani ${ }^{1)}$, Indra Kurniawan ${ }^{1)}$, Ek Ajeng Rahmi Pinahayu ${ }^{1)}$ \\ 1) Universitas Indraprasta PGRI \\ Corresponding author: ekajeng_rabmipinahayu@yahoo.com
}

\begin{abstract}
The aim of this research is knowing whether research instrument is feasible or no to get data of research. The instrument of this research is logical mathematics quotient test with 25 problems in multiple choice and mathematics problem solving test with 4 questions in essay. Testing the appropriateness of instrument of logical mathematics intelligence consist of content validity, level of problem difficulties, power differentiator, and reliability. Meanwhile, testing the appropriateness of instrument of mathematics problem solving use content validity. The validator for both of logical mathematics intelligence test and mathematics problem solving test is expert judgement. There are 39 students of Senior High School as respondent who are joining instrument try out. The results of appropriateness of instrument shows there are 25 questions of logical mathematics quotient instrument which are feasible to take research data and the instrument of mathematics problem solving in linier equation system is feasible to use with some revisions from expert judgment.
\end{abstract}

Keywords:Instrument Development, logical mathematics quotient, mathematics problem solving

\section{Introduction}

Education is one of the aspects that can fulfil needs of high human-resources quality in Indonesia. Thus, it is important to develop aspects of education with purpose to increase students' quality. Hence, students can develop their creative thinking ability that they can qualify the development of globalization era and compete with others in the future. That statement is corresponding with Anwar, et al (2012) that said, "Creative thinking is viewed as crucial for educated persons to cope with a rapidly changing world". Developing creative thinking on knowledge aspect particularly is expected to make children could create and innovate solutions from some problems that they faced.

Thomas (2005) stated, "creativity is a concept through which theoretical assumptions are examined, questioned, and then shifted". Moreover, Santrock (2010) said that creativity is human ability to think about something with new and uncommon ways, and also to think about unique solution from some problems. In addition, Surhaman (2005) stated that creativity is one of human intelligence ability which is very essential. Besides, Solso (2007) stated that creativity is one of cognitive activities which produce new point of view about some problems and there is no limit product that viewed by its function. As well as, Howard-Jones (2002) reveal that creativity is about taking common aspect or common solution become new and valuable aspect or solution. 
Based on that explanation, it can be concluded that creativity is intellectual human-ability in thinking to find new aspects or solutions for solving certain problems.

Siswono (2004) stated that creative thinking process is steps of creative thinking which consist of synthesis idea, build idea, then plan application of idea, and apply the idea to produce new product. Particularly, synthesis idea is combining ideas which are from learning activities in class or daily experiences. In addition, Wallas (from Solso, 2007) said that there are 4 steps of creative thinking process, namely preparation, incubation, illumination, and verification. In this research, to identify students creative thinking process and as guide to analyze the data is used Wallas theory as this theory is common theory that used by people to determine students creative thinking process.

Based on Baiduri (2014), a problem is mathematics problems if the problems is challenging for students and typically solved by routine ways like teacher do as usual. When students are faced by mathematics problems and they can solve them, it means that the students have no problem to solve the mathematics problems. However, students have difficulties to solve mathematics problems if they cannot solve that problems well. Related to the definition of mathematics problems, Bey (2004) stated that mathematics problem solving is high order thinking process as the most essential aspect in mathematics problem solving is the process to find solution until the exact solution is accomplished. Based on that explanation, it can be summarized that indicators of problems that include mathematics problems is more than one way available to solve the problems or it called by open ended question.

Gardner (2013) identified that there are 7 kinds of human quotient with difference level of development. They are musical intelligence, gestures intelligence, logical mathematics intelligence, linguistic intelligence, spatial intelligence, intrapersonal intelligence, and interpersonal intelligence. Based on 7 kinds of human intelligence, logical intelligence has role in mathematics problem solving. Moreover, Gardner (2007) defined logical mathematics intelligence as ability to handle relevance or argumentation about pattern and sequence. Understanding pattern and sequence case need logical thinking method. Differences of students thinking method could be developed in order to have good logical intelligence. Each intelligence depend on accuracy observation and assessment, understanding and ability to predict sequential event naturally. Each intelligence has their own indicators and the logical mathematics intelligence too. Based on definition and expert argument described previously, the indicators of logical mathematics intelligence in this research are: (1) ability to analyze problems logically, (2) sequence numbers ability, (3) algebra ability.

According to Arikunto (2000), instrument that used to collect data is a tool which is selected and used by researcher in collecting data activities in order to make it systematic and easy. In addition, Hadjar (1996) claimed that instrument is measuring tool that used to get quantitative information about various characteristic variable objectively. Besides, instrument for collecting data according to Suryabrata (2008) was a tool that used to record the condition and activities of psychology, generally in quantitative. Based on some opinions, it can be concluded that research instrument is tool that used by researcher to collect quantitative information about research variable. Particularly, instruments that used in this research are logical mathematics intelligence test which is multiple choice and mathematics problem solving test which is essay. Besides, material of the test is linear equations system.

The instrument should be tried out first, before the instrument is used to collect data, then it is analyzed to identify the validation, power differentiator, difficulties level of problems and reliability. Based on that description, the aim of this research is knowing whether the instrument that used in research with title, "Creative Thinking Process in 
Mathematics Problem Solving Based on Logical Mathematics Intelligence" is feasible or no to get data of research.

\section{Research Methods}

This research is descriptive qualitative research with research method is Research and Development. The number of school and students who become sample of this research are selected by multistage sampling technique. The purposive technique is used to determine the subject of this research. Iskandar (2008) explained the steps for arranging research instrument, they are: (1) identify the variables that would be researched, (2) describe variables become dimensions, (3) determine indicators of every dimensions, (4) describe instrument outline, (5) formulate questions or statement of instrument, and (6) make instruction of filling the instrument.

This research uses instrument about logical mathematics intelligence test with multiple choice of 30 questions and mathematics problem solving test which is essay with 4 problems. Testing the appropriateness of logical mathematics intelligence instrument consist of content validity, difficulties level of problems, power differentiator, and reliability. Meanwhile, testing the appropriateness of mathematics problem solving instrument only use content validity. The validator for both of logical mathematics quotient test and mathematics problem solving test is expert judgement. There are 39 students of Senior High School as respondent who are joining instrument try out

\section{Results and Discussion}

Before collecting data of research, the question are tried out first to measure students logical mathematics intelligence. Test of logical mathematics intelligence consist of 30 questions. Each questions consist of 4 choices answers. Logical mathematics intelligence test is tried out at a tenth grade high school students in Depok regency, Jakarta which consists of 39 students. The result of logical mathematics intelligence test is that 25 questions could be used to take data of research. Those are the completely description about the try out result of students logical mathematics intelligence test.

\section{Content Validation}

Before students were taking test of logical mathematics intelligence, the instrument is validated the content by expert judgement. Criteria of review this content validation are material or content, construction, and language. Assessment of content validation used check list $(\sqrt{ })$. Then, the instrument is reviewed by 3 validator based on content validation sheet. The result of content validation showed that all questions were appropriate with the criteria but there is some revision in structure of sentence that used. After that, all questions of logical mathematics intelligence test were valid thus it was ready to try out.

\section{Discrimination Index}

Table 2 presents the summary of calculation result about power differentiator in student's logical mathematics intelligence test. Item of question that used to identify competence of student's mathematics knowledge is item that have good power differentiator, it is $r_{x y} \geq 0,30$. Based on the calculation result at Table 2, there are 27 questions from 30 questions which have good power differentiator. 
Table 2.

Discrimination Index in Logical Mathematics Intelligence Test

\begin{tabular}{cccc}
\hline $\begin{array}{r}\text { Power } \\
\text { Differentiator }\end{array}$ & Criterion & Item of Question & Conclusion \\
\hline$r_{x y}<0,30$ & Not Good & $6,9,13$ & Deleted \\
\hline \multirow{2}{*}{$r_{x y} \geq 0,30$} & \multirow{2}{*}{ Good } & $\begin{array}{c}1,2,3,4,5,7,8,9,10,11,12, \\
\end{array}$ & \\
& & $23,24,25,26,27,28,29,30$ & Used \\
\hline
\end{tabular}

\section{Difficulty index of item}

Table 3 presents the summary of calculation result about difficulties index of questions in logical mathematics intelligence test. Item of question that used to identify competence of student's mathematics knowledge is item that have difficulty index in medium level, it is $0,3 \leq T K \leq 0,7$. Based on the calculation result at Table 3, there are 27 questions from 30 questions which have medium index of difficulties.

Table 3.

Difficulty index of Questions in Logical Mathematics Intelligence Test

\begin{tabular}{ccc}
\hline Difficulties Index & Item of Question & Conclusion \\
\hline $\begin{array}{c}0,00 \leq T K<0,30 \\
\text { Difficult }\end{array}$ & 6 & Deleted \\
\hline $\begin{array}{c}0,30 \leq T K \leq 0,70 \\
\text { Medium }\end{array}$ & $\begin{array}{c}1,2,3,4,5,7,8,10,11,12,14, \\
15,17,18,19,20,21,22,23, \\
24,25,26,27,28,29,30\end{array}$ & Used \\
\hline $\begin{array}{c}0,70<T K \leq 1,00 \\
\text { Easy }\end{array}$ & 9,13 & Deleted \\
\hline
\end{tabular}

\section{Reliability}

Based on calculation result of difficulties level and power differentiator in student's logical mathematics intelligence test, there are 27 questions from 30 questions that could be used. Then, there are 25 questions that use to measure student's logical mathematics intelligence, they are: $1,2,3,5,7,8,10,11,12,14,15,16,17,18,19,20,21,22,23,24$, $25,26,27,28$, and 29. Because of that, there are 2 questions that were not used although the two questions include on good question. Despite two questions were not used, the indicators of student's logical mathematics intelligence were represented at the others.

After that, the 25 good questions were calculated index of reliability based on difficulties level and power differentiator. The test which consist of 25 questions were used if it had $r_{11} \geq 0,70$. Meanwhile, the result of reliability index calculation was 0,87 . Thus, based on that calculation result, the test was set by instrument that used to collect data of student's logical mathematics intelligence.

\section{Validation of Interview Guided and Mathematics Problem Solving Test}

Before taking test of mathematics problem solving and interview to students, the instrument is validated the content by expert judgement. Then, the instrument is reviewed by 3 validator based on content validation sheet. The result of content validation by validator stated that guided interview and mathematics problem solving test were appropriate with the criteria but there is some revision in structure of sentence that used. After that, the guided interview and mathematics problem solving test were valid thus both of them were ready to take data of research. 
Because of this research use time triangulation, then mathematics problem solving test is done two times. Those are the questions of first mathematics problem solving test: 1. Given a number consist of 3 digits. Total of 3 digits is 9. The unit numbers is number dozens plus three. If number of hundreds and number of dozens is exchanged the location, then the result is same numbers. Determine that number.

2. A lens factory has 3 machines, namely machine A, B, and C. If three of them work together, then it produce 5.700 lens for a week. If machine A and B work together, then 3.400 lens is produced for a week. Meanwhile, if machine A and C work together, then there are 4.200 lens which are produced for a week. How many lens could be produced by each machine for a week?

Those are the questions of second mathematics problem solving test:

1. Given 3 numbers with total of them is 12 . The total of first number and second number is 7. Meanwhile, if second number is multiplied by 2 and added by third number, then the result is 3 . Determine the three numbers.

2. A shop sell various kinds of fruits such as orange, salak, and apple. Ani buys $1 \mathrm{~kg}$ orange, $3 \mathrm{~kg}$ salak, and $2 \mathrm{~kg}$ apple. She has to pay Rp 33.000. Meanwhile, Dina buys 2 $\mathrm{kg}$ orange, $1 \mathrm{~kg}$ salak, and $1 \mathrm{~kg}$ apple. She has to pay Rp 23.500. Besides, Rita buys 1 $\mathrm{kg}$ orange, $2 \mathrm{~kg}$ salak, and $3 \mathrm{~kg}$ apple and she should pay Rp 36.500. Based on that information, how much the price of salak, orange, and apple each $\mathrm{kg}$ ?

Those are some questions in guided interview such as: (1) Do you know the essential information from that problems? (2) What do you do to get the essential information? Explain! (3) Do you use all essential information to solve the problem?, (4) What does the problem about? Describe with your own statement!, (5) Have you gotten idea to solve that problem?, (6) What is your reason why you choose that way? Do you convince with your idea? If you have been convinced, solve that problem with your idea!, (8) Could you use new way to solve that problem? What is your reason why you choose that way?, (9) Do you convince with your different idea? If you have been convinced, solve that problem with your idea!, (10) How do you test and check your answer?

\section{Conclusion}

Based Based on the discussion above, the conclusion are: (1) Instrument of logical mathematics intelligence test has 25 questions which are feasible to collect data of research as they fulfil specification of validation, difficulty index, good determination index, and reliability, (2) instrument of mathematics problem solving in linier equation system material is feasible to be used with some revisions from expert judgment. We suggest that it is better for trying out the appropriateness of research instrument first before it is used to collect data of research. It recommend to do as it can identify whether the instrument really measure what will be measured. Besides, the information about try out of instrument such as content validation, difficulties level of problems, good power differentiator, and reliability, is suggested to be published as it would persuade reader that instrument of research really feasible to collect data of research.

\section{Acknowledgement}

Appreciation and gratefulness for Direktorat Riset dan Pengabdian Masyarakat, Dirjen Penguatan Riset dan Pengembangan, Kementrian Riset, Teknologi dan Pendidikan Tinggi who have been fund the national competitive research Penelitian Dosen Pemula (PDP) year 2017 with title "Proses Berpikir Kreatif dalam Pemecahan Masalah Matematika Ditinjau dari Kecerdasan Logis Matematis di Kota Depok". Besides, thank you for Kopertis Wilayah III Jakarta and Lembaga Penelitian dan Pengabdian Masyarakat Universitas Indraprasta PGRI who helped this research through Research 
agreement No: 0428/K3/KM/2017, on 24 Mei 2017 and agreement letter of UNINDRA No 0588/SKP.LT/LPPM/UNINDRA/VI/2017, on 05 Juni 2017.

\section{References}

Anwar, M.N., Aness, M., Khizar, A., Nasser, M., dan Muhammad, G. (2012). Relationship of Creative Thinking with the Academic Achievements of Secondary School Students.International Interdisciplinary Journal of Education, 1(3), pp. 44-47.

Arikunto, S. (2000). ManajemenPenelitian. Jakarta: RinekaCipta.

Baiduri. (2014). A Relational Thinking Process of Elementery School Students with High Capability. Journal of Educational and Developmental Psychology, 4: 24-34.

Bey, A. (2014). Developing Skills Resolution Mathematical Primary School Students. International Journal of Education and Research, 2(10), pp. 601-614.

Budiyono. (2003). Metodologi Penelitian Pendidikan. Surakarta: UNS Press.

Budiyono. (2011). Penilaian Hasil Belajar. Surakarta: UNS Press.

Eberle, G Scoot. (2011). Playing with the Multiple Intelligences How Play Help Them Grow. American Journal of Play, 4 (1), pp. 19-51.

Gardner, Howard. (2013). Buku Multiple Intelligences. Kecerdasan Majemuk. Terjemahan Oleh Lyndon Saputra. Tangerang: Interaksara.

Hadjar, I. (1996). Dasar-dasar Metodologi Penelitian Kuantitatif dalam Pendidikan. Jakarta: Raja GrafindoPersada.

Hendriyadi. (2014). Content Validity (Validitas Isi). [Online]. Tersedia: https://teorionline.files.wordpress.com/2014/07/010614-content-validity.pdf.

[Diakses 3 Oktober 2017]

Howard-Jones, P. A. (2002). A Dual-State Model of Creative Cognition for Supporting Strategies that Foster Creativity in the Classroom. International Journal of Tecbnology and Design Education,12, pp. 215-226.

Iskandar. (2008). Metodologi Penelitian Pendidikan dan Sosial (Kuantitatif dan Kualitatif). Jakarta: GaungPersada Press.

Santrock, J.W. (2010).Psikologi Pendidikan. Jakarta: PT Salemba Humanika.

Siswono, T.Y.E. (2011).Level of Student's Creative Thinking in ClassromMathematics. Academic Journal Education Research and Review, 6(7), pp. 548-553.

Solso, R.L. (2007).Psikologi Kognitif. PT. GeloraAksaraPratama.

Suharnan. (2005). Psikologi Kognitif. Surabaya: Srikandi.

Suryabrata, S. (2008). Metodologi Penelitian. Jakarta: RinekaCipta.

Thomas, M. (2005). Creative Thinking and Talking in Residential Care. Therapeutic Community. The International Journal for Therapeutic and Supportive Organizations, 26(1), pp. 115-125. 


\section{Appendix A}

\section{Logical Matematical Intellegence Test}

1. Jika hari ini hujan, maka Atika tidak berangkat sekolah. Atika berangkat sekolah, maka ... .
a. Hari ini hujan
b. Hari ini mendung
c. Hari ini tidak hujan
d. Hari ini libur

2. Semua makhluk hidup bernapas. Semua hewan adalah makhluk hidup, maka ... .
a. Semua yang bernapas pasti hidup
b. Ada hewan yang makhluk hidup
c. Semua makhluk hidup ada yang hewan
d. Semua hewan bernapas

3. Semua anggota tim olimpiade matematika dari Indonesia memakai sepatu merk "Nike". Sebagian anggota tim berhasil meraih medali emas. Manakah yang bukan merupakan kesimpulan dari pernyataan di atas?

a. Berkat merk sepatu "Nike", kontestan Indonesia meraih medali emas

b. Peraih medali emas dari Indonesia memakai sepatu merk "Nike"

c. Semua orang yang memakai sepatu merk "Nike" meraih medali emas

d. Anggota tim olimpiade yang memakai sepatu merk "Nike" meraih medali emas.

4. Semua radio memakai baterai. Sebagian radio tidak memakai antena panjang. Hal ini berarti ... .
a. Semua radio yang tidak memakai baterai, berantena panjang
b. Ada radio yang tidak memakai baterai, berantena panjang
c. Semua radio yang memakai baterai, tidak berantena panjang
d. Ada radio yang memakai baterai, tidak berantena panjang

5. Setiap siswa berprestasi pasti terkenal di sekolahnya. Setiap siswa yang aktif dalam pembelajaran pasti berprestasi. Sebagian siswa SMP Negeri 2 Juwiring terkenal di sekolahnya. Hal ini berarti ... .

a. Ada siswa yang aktif dalam pembelajaran, tetapi tidak terkenal di sekolahnya

b. Sebagian siswa yang aktif dalam pembelajaran tidak terkenal di sekolahnya

c. Siswa yang aktif dalam pembelajaran pasti terkenal di sekolahnya

d. Sebagian siswa yang berprestasi namun tidak terkenal di sekolahnya

6. Kendaraan roda tiga dilarang masuk jalan tol. Sementara becak beroda empat. Apakah kesimpulannya?

a. Becak tidak dilarang masuk jalan tol

b. Becak dilarang masuk jalan tol

c. Becak harus masuk jalan tol

d. Becak diperbolehkan masuk di jalan apapun

7. Rani dan Rina adalah kakak beradik, jika Rani suka alpukat maka Rina suka jeruk. Rani menyukai semua jenis buah-buahan. Hal ini berarti ... .
a. Rina suka alpukat.
b. Rani suka yang Rina juga suka.
c. Rani tidak suka alpukat.
d. Rina dan Rani suka alpukat.

8. Jika harga BBM naik, maka harga bahan pokok naik. Jika harga bahan pokok naik, maka ada orang tidak senang. Ingkaran/negasi dari kesimpulan tersebut adalah ... . a. Harga BBM naik dan ada orang senang. 
b. Jika harga bahan pokok naik, maka ada orang tidak senang.

c. Harga bahan pokok naik atau ada orang tidak senang.

d. Jika semua orang tidak senang, maka harga BBM naik.

9. Ali adalah kakak Hasan, 4 tahun lebih tua. Sinta adalah kakak Ali dan berbeda 3 tahun. Berapakah usia Sinta, jika saat ini Hasan baru saja merayakan ulang tahun yang ke-21?
a. 14
b. 21
c. 25
d. 28

10. Seorang pedagang menjual jambu dengan harga Rp 15.000,00/kg. Di dalam tokonya terdapat 6 dus dan di setiap dus berisi $5 \mathrm{~kg}$ jambu. Dus bekas tempat jambu itu masih bisa dijual lagi dengan harga $\mathrm{Rp} 2.000,00$ /dus. Berapakah uang hasil penjualan seluruh jambu dan dus tersebut?
a. Rp. $75.000,00$
b. Rp. $450.000,00$
c. Rp. $452.000,00$
d. Rp. $462.000,00$

11. Harga sewa mobil di sebuah persewaan mobil adalah Rp 150.000,00/24 jam pertama, sedangkan tiap kelebihan dua jam berikutnya dikenai denda $\mathrm{Rp}$ 15.000,00. Jika suatu hari, Jerry menyewa sebuah mobil dan diharuskan membayar Rp 165.000,00. Berapa lama Jerry menyewa mobil tersebut?
a. $24 \mathrm{jam}$
b. 26 jam
c. $28 \mathrm{jam}$
d. $30 \mathrm{jam}$

12. Seseorang ingin memasang iklan sebanyak 5 baris untuk menjual sepeda motornya. Untuk hari pertama, biaya yang harus dikeluarkan $\mathrm{Rp} 200,00 /$ baris. Untuk hari berikutnya, biayanya adalah $\mathrm{Rp} 100,00$ per baris per hari. Jika ia membayar Rp $3.500,00$. Berapa lama iklan itu dipasang?
a. 6 hari
b. 9 hari
c. 10 hari
d. 12 hari

13. Untuk memasang 4 buah ketel, dibutuhkan persediaan batu bara selama 2 minggu. Berapa lama persediaan batu bara yang dibutuhkan untuk memanaskan 20 buah ketel?
a. 5 minggu
b. 10 minggu
c. 15 minggu
d. 20 minggu

14. Seorang pedagang membeli beberapa ekor anak kambing dengan harga Rp 500.000,00. Kemudian, ia menjualnya seharga Rp 600.000,00 dan mendapatkan keuntungan Rp 50.000,00 per ekor anak kambing. Berapa ekor anak kambing yang dibeli atau dijual?
a. 1 ekor
b. 2 ekor
c. 3 ekor
d. 4 ekor 
15. Di kantong terdapat permen untuk 20 orang anak (tanpa sisa), dimana tiap anak akan memperoleh 12 permen. Jika ada 5 anak yang tidak menginginkan permen tersebut maka banyaknya permen yang akan diberikan kepada anak-anak yang lainnya adalah...
a. 12
b. 15
c. 16
d. 18

16. Harga sepasang sepatu mula-mula Rp. 200.000,00. Kemudian, diberi diskon 50\%. Berapa harga sepatu tersebut sekarang?
a. Rp. $50.000,00$
b. Rp. $75.000,00$
c. Rp. $100.000,00$
d. Rp. $125.000,00$

17. Berapa biaya yang diperlukan untuk mengecat dinding yang panjangnya $6 \mathrm{~m}$ dan tingginya $3 \mathrm{~m}$, bila per $\mathrm{m}^{2}$ diperlukan biaya Rp. $5.000,00$ ?
a. Rp. $75.000,00$
b. Rp. $80.000,00$
c. Rp. $85.000,00$
d. Rp. $90.000,00$

18. $1,4,8,11,15, \ldots$.

Seri selanjutnya adalah...
a. 17
b. 18
c. 19
d. 20

19. Tentukan bilangan selanjutnya...

$2,4,8,14,22, \ldots$.
a. 30
b. 32
c. 34
d. 36

20. Suatu seri : $14,16,19,21,24, \ldots$.

Seri selanjutnya adalah...
a. 20
b. 22
c. 25
d. 26

21. Tentukan bilangan selanjutnya... $-4,-3,0,5,12, \ldots$.
a. 17
b. 19
c. 21
d. 23

22. Tentukan bilangan selanjutnya... $17,21,23,27, \ldots$.
a. 33
b. 32
c. 31
d. 29 
23. $4,2,12,6,36, \ldots, \ldots, 54$.

Isilah kedua bilangan pada tempat yang kosong di atas.
a. 18 dan 108
b. 24 dan 18
c. 24 dan 108
d. 74 dan 108

24. $18,16,0,19,17,0, \ldots, \ldots$.

Bilangan selanjutnya adalah...
a. 18 dan 20
b. 20 dan 18
c. 21 dan 18
d. 22 dan 20

25. $75,97,60,92,45, \ldots$.

Bilangan selanjutnya adalah...
a. 54
b. 75
c. 78
d. 87 


\section{Appendix B}

\section{Problem Solving Test 1 and Problem Based Interview}

1. Sebuah bilangan terdiri atas tiga angka. Jumlah dari ketiga angka tersebut adalah 9. Angka satuannya ialah angka puluhan ditambah tiga. Jika angka ratusan dan angka puluhan ditukar letaknya, diperoleh bilangan yang sama. Tentukan bilangan tersebut!

a. Apakah Anda mengetahui informasi penting dari soal di atas?

b. Hal apa saja yang anda lakukan untuk mendapatkan informasi penting tersebut? Berikan penjelasan!

c. Apakah Anda menggunakan semua informasi penting untuk memecahkan masalah tersebut?

d. Berkaitan dengan apa permasalahan tersebut? Jelaskan dengan bahasamu sendiri!

e. Apakah Anda telah mendapatkan ide untuk menyelesaikan soal itu?

f. Apa alasan Anda menggunakan cara tersebut?

g. Apakah Anda yakin dengan ide Ada tadi? Jika Anda telah yakin, selesaikan masalah tersebut dengan ide Anda!

h. Apakah Anda dapat menggunakan cara yang baru dalam menyelesaikan permasalahan itu? Apa alasan Anda menggunakan cara tersebut?

i. Apakah Anda yakin dengan cara berbeda tersebut? Jika Anda telah yakin, selesaikan masalah tersebut dengan ide Anda!

j. Bagaimana cara Anda menguji dan memeriksa kembali jawabannya?

2. Sebuah pabrik lensa memiliki 3 buah mesin, yaitu mesin A, B dan C. Jika ketiganya bekerja secara bersama-sama, maka 5.700 lensa dapat dihasilkan dalam waktu satu minggu. Jika hanya mesin A dan B bekerja, maka 3.400 lensa dihasilkan dalam waktu satu minggu. Sementara itu, jika mesin A dan C yang bekerja, maka 4.200 lensa dihasilkan dalam waktu satu minggu. Berapa lensa yang dapat dihasilkan oleh tiap-tiap mesin dalam waktu satu minggu?

a. Apakah Anda mengetahui informasi penting dari soal di atas?

b. Hal apa saja yang anda lakukan untuk mendapatkan informasi penting tersebut? Berikan penjelasan!

c. Apakah Anda menggunakan semua informasi penting untuk memecahkan masalah tersebut?

d. Berkaitan dengan apa permasalahan tersebut? Jelaskan dengan bahasamu sendiri!

e. Apakah Anda telah mendapatkan ide untuk menyelesaikan soal itu?

f. Apa alasan Anda menggunakan cara tersebut?

g. Apakah Anda yakin dengan ide Ada tadi? Jika Anda telah yakin, selesaikan masalah tersebut dengan ide Anda!

h. Apakah Anda dapat menggunakan cara yang baru dalam menyelesaikan permasalahan itu? Apa alasan Anda menggunakan cara tersebut?

i. Apakah Anda yakin dengan cara berbeda tersebut? Jika Anda telah yakin, selesaikan masalah tersebut dengan ide Anda!

j. Bagaimana cara Anda menguji dan memeriksa kembali jawabannya? 


\section{Problem Solving Test 2 and Problem Based Interview}

1. Diberikan tiga buah bilangan dengan jumlah ketiganya adalah 12. Jumlah bilangan pertama dan kedua adalah 7, sedangkan jika bilangan kedua dikalikan dua dan ditambah bilangan ketiga maka dihasilkan 3. Tentukan bilangan-bilangan tersebut!

a. Apakah Anda mengetahui informasi penting dari soal di atas?

b. Hal apa saja yang anda lakukan untuk mendapatkan informasi penting tersebut? Berikan penjelasan!

c. Apakah Anda menggunakan semua informasi penting untuk memecahkan masalah tersebut?

d. Berkaitan dengan apa permasalahan tersebut? Jelaskan dengan bahasamu sendiri!

e. Apakah Anda telah mendapatkan ide untuk menyelesaikan soal itu?

f. Apa alasan Anda menggunakan cara tersebut?

g. Apakah Anda yakin dengan ide Ada tadi? Jika Anda telah yakin, selesaikan masalah tersebut dengan ide Anda!

h. Apakah Anda dapat menggunakan cara yang baru dalam menyelesaikan permasalahan itu? Apa alasan Anda menggunakan cara tersebut?

i. Apakah Anda yakin dengan cara berbeda tersebut? Jika Anda telah yakin, selesaikan masalah tersebut dengan ide Anda!

j. Bagaimana cara Anda menguji dan memeriksa kembali jawabannya?

2. Sebuah kios menjual bermacam-macam buah di antaranya jeruk, salak, dan apel. Ani membeli $1 \mathrm{~kg}$ jeruk, $3 \mathrm{~kg}$ salak, dan $2 \mathrm{~kg}$ apel, ternyata ia harus membayar $\mathrm{Rp}$ 33.000,00. Sementara itu, Dina membeli $2 \mathrm{~kg}$ jeruk, $1 \mathrm{~kg}$ salak, dan $1 \mathrm{~kg}$ apel, ternyata ia harus membayar Rp 23.500,00. Lain halnya dengan Rita yang membeli 1 $\mathrm{kg}$ jeruk, $2 \mathrm{~kg}$ salak, dan $3 \mathrm{~kg}$ apel, ternyata ia harus membayar Rp 36.500,00. Berdasarkan infromasi di atas, berapakah harga per kilogram salak, jeruk, dan apel?

a. Apakah Anda mengetahui informasi penting dari soal di atas?

b. Hal apa saja yang anda lakukan untuk mendapatkan informasi penting tersebut? Berikan penjelasan!

c. Apakah Anda menggunakan semua informasi penting untuk memecahkan masalah tersebut?

d. Berkaitan dengan apa permasalahan tersebut? Jelaskan dengan bahasamu sendiri!

e. Apakah Anda telah mendapatkan ide untuk menyelesaikan soal itu?

f. Apa alasan Anda menggunakan cara tersebut?

g. Apakah Anda yakin dengan ide Ada tadi? Jika Anda telah yakin, selesaikan masalah tersebut dengan ide Anda!

h. Apakah Anda dapat menggunakan cara yang baru dalam menyelesaikan permasalahan itu? Apa alasan Anda menggunakan cara tersebut?

i. Apakah Anda yakin dengan cara berbeda tersebut? Jika Anda telah yakin, selesaikan masalah tersebut dengan ide Anda!

j. Bagaimana cara Anda menguji dan memeriksa kembali jawabannya? 